\title{
SELECTED BIOLOGICAL CHARACTERISTICS OF THE CATCH- AVAILABLE PART OF POPULATION OF VENDACE, COREGONUS ALBULA (L.) FROM LAKE MIEDWIE, POLAND
}

\author{
Przemysław CZERNIEJEWSKI ${ }^{1 *}$, Jarosław FILIPIAK ${ }^{1}$ \\ Gorzysław POLESZCZUK ${ }^{2}$, Wawrzyniec WAWRZYNIAK ${ }^{1}$
}

${ }^{1}$ Division of Fisheries Management in Open Waters, Agricultural University of Szczecin, Szczecin, Poland

${ }^{2}$ Faculty of Natural Sciences, University of Szczecin, Szczecin, Poland

Czerniejewski P., Filipiak J., Poleszczuk G., Wawrzyniak W., 2004. Selected biological characteristics of the catch-available part of population of vendace, Coregonus albula (L.) from Lake Miedwie, Poland. Acta Ichthyol. Piscat. 34 (2): 219-233.

Background. Due to its economical importance the vendace has been considered one of the most important items of the ichthyofauna of Polish lakes. This is mainly because of favourable biological features of this species, namely: short (2-3 years) period of attaining market size, relatively fast growth rate, schooling behaviour facilitating catches, and most of all the high meat value, making it a desirable consumer item.

Material and methods. Biological characters were determined in 451 vendace from Lake Miedwie, caught in spring, (124 individuals), summer (132), late summer (87), and autumn (108). The age and growth rates of the fish were determined based on scales using commonly accepted methods. Fulton- and Clark coefficients were used to determine the fish condition.

Results. The fish caught were 180-294 mm-long (TL) and weighed 45.2-176.3 g. Mean values of the Fulton coefficient indicated a pronounced improvement in the fish condition from spring to later summer ( 0.70 and 0.80 , respectively) and a slight reduction in autumn (0.75). The age composition of the fish was as follows: 1+, 213 individuals (47.2\%); 2+, 229 ind. (50.8\%); 3+, 9 ind. (2.0\%). The von Bertalanffy equations that describe theoretical growth of the fish examined in length $(L \mathrm{t})$ and weight $(W \mathrm{t})$, were calculated.

Conclusion. According to the generally accepted criteria of the vendace growth rate, the Lake Miedwie individuals showed a very good growth, higher than that recorded in populations inhabiting other whitefish lakes of Polish Western Pomerania, which indicates the availability of appropriate food resources for the vendace in the Miedwie.

Key words: fish, vendace, Coregonus albula, growth rate, mathematical growth models, condition coefficient, Lake Miedwie.

* Correspondence: Dr Przemysław Czerniejewski, Zakład Gospodarki Rybackiej na Wodach Otwartych, WNoŻiR, Akademia Rolnicza, ul. Kazimierza Królewicza 4, 71-550 Szczecin, Poland, e-mail: zgl@fish.ar.szczecin.pl 


\section{INTRODUCTION}

In Poland, the vendace, Coregonus albula (Linnaeus, 1758) is a commercially important fish species. It commonly takes up 2-3 years, to grow to the market size (Marciak 1970, Ciepielewski 1974a, Czerniejewski et al. 2002). The species forms schools, which facilitates harvesting (Dembiński 1971). The meat is white, bone-free, and very well tasting, for which reason the fish is in great demand among consumers (Brylińska 1986).

The vendace occurs in 44 lakes within the province of Polish Western Pomerania and is harvested commercially in 23 lakes (Filipiak and Raczyński 2000, Czerniejewski and Filipiak 2001). Within 1950-1970, Lake Miedwie was a preferred fishing area for vendace. However, during the next 25 years, the stock collapsed and the species was caught only sporadically. The unaided recovery of the stock in the mid-1990s (Pietrucha 1999, Anonymous 2002) prompted the authors to commence research aimed at assessing the current age structure, condition, and growth rate of the Miedwie population and to compare the data with corresponding information on the vendace caught in other lakes.

Lake Miedwie: general characteristics

Lake Miedwie, with its area of 3527 ha and $19.3 \mathrm{~m}$ average depth $(43.8 \mathrm{~m}$ maximum depth), is the second largest Lake in Western Pomerania. The lake is troughshaped; its maximum length and width are $16.2 \mathrm{~km}$ and $3.2 \mathrm{~km}$, respectively; the littoral zone is narrow. The lake's volume averages 681.1 million $\mathrm{m}^{3}$ (Jańczak 1996).

The Miedwie is a flow-through lake for the Płonia River, a right-bank tributary of the Odra. The lake receives also the discharge of the streams Ostrowica, Miedwianka, Gowienica Miedwiańska, and Rów Kunowski. The outflow down the Płonia is controlled by a weir located near the village of Żelewo.

According to Szyper and Gołdyn (1990), the Miedwie's water is completely exchanged during 3 years and 9 months. The lake is fed in $73 \%$ by the surface runoff, ground waters and atmospheric precipitation accounting for 16 and $11 \%$ of the total inflow, respectively. The total catchment covers about $1017 \mathrm{~km}^{2}$. This is an area of intensive agriculture (more than $60 \%$ of the area are arable fields). The direct catchment of about $57 \mathrm{~km}^{2}$ is dominated by grazing meadows.

Until the 1920s, Lake Miedwie was oligotrophic (Żmudziński 2003). Despite its high natural resistance to anthropogenic impact (category 1 of the Lake Quality Assessment System of Kudelska et al. 1992), the lake succumbed-particularly after the World War II — to the pressure exerted by excessive pollution (Anonymous 1999, Tórz et al. 2003). At the end of the 1970s, the lake's water quality deteriorated, which resulted in important changes in the biota: degradation and disappearance of benthic communities (Żmudziński 2003) and qualitative and quantitative changes in the fish fauna. The lake's degradation proceeded despite the fact that, since 1976, the lakes has been serving as a drinking water reservoir for the city of Szczecin (about 50\% of the water feeding the lake is used for the purpose), because of which the lake was 
surrounded by zones of direct and indirect protection. Unfortunately, the Miedwie's water quality did not improve discernibly, because the water discharged into it was still of a very poor quality (Tórz et al. 2003). It was only since 1992, after a sewage treatment plant at Pyrzyce had began operating and after a litter-free animal husbandry in farms located within the direct catchment of the lake had been phased out, and also after further 9 sewage treatment plants were opened in the mid-1990s, that the water quality began to gradually improve. Although the legal regulations limit the phosphorus content in treated sewage discharged directly or indirectly into the Miedwie to 1-1.5 mg P.1-1 the considerable amounts of phosphorus accumulated in the lake continued, in the mid-1990s, to cause frequent manifestations of eutrophication to appear (anoxia at depths exceeding 15-20 m, phytoplankton blooms of various intensity). A marked improvement in the Miedwie water quality has been observed since as late as 1998 (Tórz et al. 2003). According to environmental assessments, the Miedwie water at that time represented quality class II. Based on total phosphorus and chlorophyll ' $a$ ' contents reported by Tórz et al. (2003), the lake could be classified as mesotrophic (Vollenweider and Kerekes 1982). The recent improvement in the Miedwie water quality is evidenced by an increase in the abundance of the relict amphipod Pallasea quadrispinosa (Sars, 1867) and by, e.g. a vendace landing of about $8056 \mathrm{~kg}$ in 1998, which is a sign of a natural (unaided, without stocking) recovery of the population of that fish (Fig. 1) (Pietrucha 1999, Anonymous 1999, 2002).

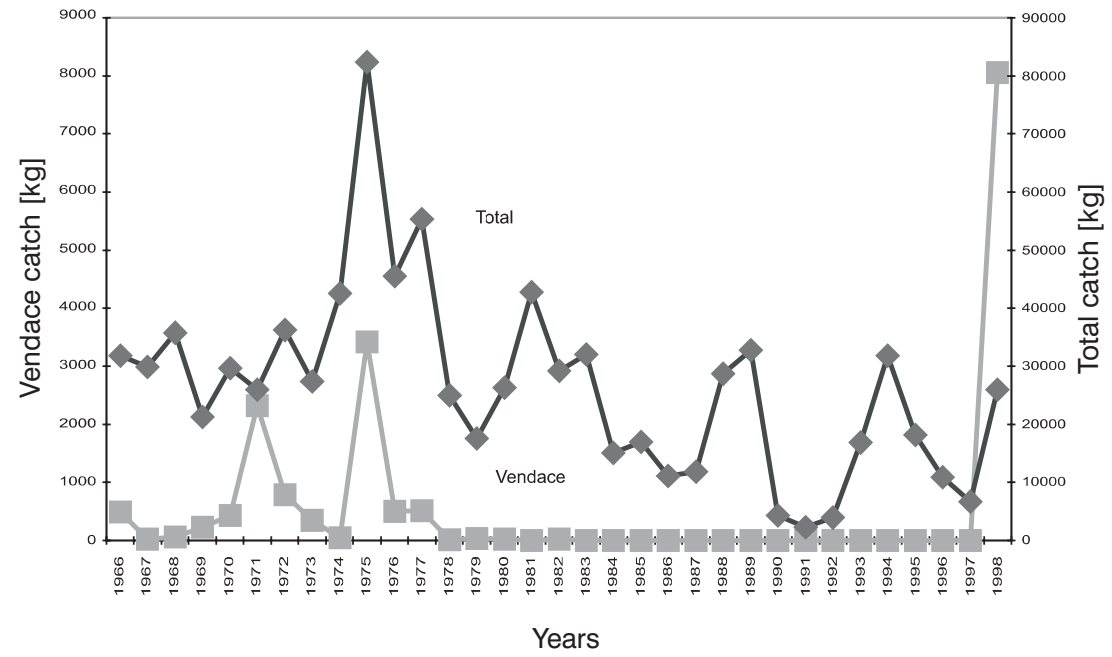

Fig. 1. Dynamics of vendace catches in relation to total fish catch in Lake Miedwie (original data) 


\section{MATERIALS AND METHODS}

The vendace examined were caught in 1998, during nighttime fishing with 24-26 $\mathrm{mm}$ mesh size stationary gill nets deployed in the central part of Lake Miedwie. The nets were most often deployed at the depth of 14-20 m at arbitrarily chosen sites and times. The entire period of study was divided, by convention, into four fishing seasons: spring, summer, late summer, and autumn. In each season, $2-5 \%$ of the catch were randomly picked out for examination. The spring catches entailed those obtained on 23 March (25 individuals retrieved) and 2 April (99 ind.); the summer catches consisted of those obtained on 29 June (57 ind.) and 14 July (75); the late summer catches were those obtained on 18 August (40), and 9 September (47); finally, the autumn catches were those obtained on 16 and 25 November (a total of 108 individuals retrieved). Altogether, 451 individuals were retrieved for the study.

Individual weight $\left(W_{1}\right)$ and gutted weight $\left(W_{2}\right)$ of the fish as well as gonad weight were read (to $0.1 \mathrm{~g}$ ) from an Axis electronic scales; the fish length (TL, SL, and FL) was measured (to $0.1 \mathrm{~mm}$ ) with electronic callipers. Fish condition was determined from the Fulton- and Clark condition coefficients ( $K$ and $K_{\mathrm{C}}$ respectively). The former was calculated according to a general formula of

where:

$$
K=\frac{W_{1} \cdot 10000}{L^{3}}
$$

$W_{1}$, fish total weight $[\mathrm{g}]$;

$L$, fish total length [mm].

To calculate the Clark coefficient $\left(K_{\mathrm{C}}\right)$, the total weight $\left(W_{1}\right)$ in the formula above was substituted by the gutted fish weight $\left(W_{2}\right)$. The condition coefficients were calculated separately for each individual and related to the total length, using linear functions for 10-mm length intervals.

The TL- $W_{1}$ (total length-individual weight) relationship was determined using the power function (Bagenal et al. 1978):

$$
W=a \cdot L^{b}
$$

where:

$W$, total individual weight $\left(\mathrm{W}_{1}\right)[\mathrm{g}]$;

$L$, total length (TL) [mm];

$a, b$, parameters of the $L-W$ relationship.

There are a lot of methods, listed in the relevant literature, for age determination of fishes of the family Coregonidae, for example based on: scales, rays, and otoliths. The scales, however, because of their good readability, easy way of collection, and easy way of identifying the annual rings, without prior processing, have been commonly used for aging fish, particularly 4-5 year old. (Ovchynnuk 1962). Also in the present work fish age as well as length- and weight growth rates were determined 
from the scales. They were collected as recommended by Bernatowicz (1952), cleaned of mucus remains in the ammonium-saturated water and mounted. Age was read and measurements were taken (to $0.001 \mathrm{~mm}$ ) from the oral part of the scales, using a computer image analysis software "MultiScan". The verification of fish age was based on two estimations of the fish age by another person doing this familiar with the descriptions and criteria given by Sych (1971). Due to linearity of the $R-L$ relationship ( $R$, scale radius; $L$, total length of fish), back readings were performed using the Rosa-Lee technique involving the $30 \mathrm{~mm}$ standard, i.e. the length at which scale appears in vendace (Grudniewski 1970). The empirical data obtained were used to illustrate theoretical growths of the vendace length and weight, as described by the von Bertalanffy growth model (Bagenal et al. 1978).

\section{RESULTS}

Length and individual weight

Data provided in Tables 1 and 2 suggest a lack of significant differences between subsequent fishing seasons, both in terms of the mean length (TL, SL, and FL) and fish individual weight.

The homogeneity of the samples can be explained by the mesh size effect, the mesh size remaining identical (24-26 mm) in every season. However, the analysis of data by fish sex revealed considerable differences between the first (spring and summer) and the second (late summer and autumn) halves of the year in the parameters studied. A larger difference in the mean individual weight between males and females in the second half of the year was most probably caused by increasing gonad weight in the latter. In individual fishing seasons (except for autumn), females showed higher total, standard, and fork lengths, compared to males. Noteworthy is the wide range of the metric parameters, summarised in Tables 1 and 2, in each season, particularly visible in the individual weight. For example, the fish harvested in spring weighed from 45.2 to $139.6 \mathrm{~g}$; those caught in summer-from 58.6 do $135.3 \mathrm{~g}$. The fish caught in last summer showed individual weight ranging from 60.1 to $174.1 \mathrm{~g}$, while individual weight of those harvested in autumn ranged from 65.5 to $176.3 \mathrm{~g}$. Age structure and sex ratio

Among the total of 451 vendace examined, 213 (47.2\%) were aged 1+, 229 $(50.8 \%)$ were aged $2+$, and as few as 9 individuals $(2.0 \%)$ were aged $3+$. Except for the fish harvested in spring, the catches were dominated by the vendace aged $1+$. They accounted for 56,55 , and as much as $61 \%$ in the summer, late summer, and autumn sample, respectively. The unfavourable predomination of the individuals aged $1+$ in the catches may, at their heavy exploitation, have adversely affected the magnitude of catches, by weight, in the subsequent years. 
Table 1

Basic biological characteristics of the Lake Miedwie vendace (spring and summer 1998)

\begin{tabular}{|c|c|c|c|c|c|c|c|c|c|c|}
\hline \multirow{2}{*}{ Sampling period } & \multirow{2}{*}{ Sex } & \multirow{2}{*}{$\mathrm{n}$} & \multirow{2}{*}{ Value } & \multirow{2}{*}{$\begin{array}{c}\mathrm{FL} \\
{[\mathrm{mm}]}\end{array}$} & \multirow{2}{*}{$\begin{array}{c}\mathrm{SL} \\
{[\mathrm{mm}]}\end{array}$} & \multirow{2}{*}{$\begin{array}{c}\mathrm{TL} \\
{[\mathrm{mm}]}\end{array}$} & \multirow{2}{*}{$\begin{array}{c}\text { Weight } \\
\left(W_{1}\right) \\
{[\mathrm{g}]}\end{array}$} & \multicolumn{3}{|c|}{ No. of fish aged: } \\
\hline & & & & & & & & $1+$ & $2+$ & $3+$ \\
\hline 23 Mar-2 Apr & $\mathrm{F}+\mathrm{M}$ & 124 & mean & 207.8 & 196.9 & 230.8 & 86.4 & 25 & 98 & 1 \\
\hline \multirow{3}{*}{$23 \mathrm{Mar}-2 \mathrm{Apr}$} & \multirow{3}{*}{ M } & \multirow{3}{*}{85} & mean & 204.7 & 193.3 & 227.3 & 85.6 & \multirow{3}{*}{18} & \multirow{3}{*}{67} & \multirow{3}{*}{ - } \\
\hline & & & $\min$ & 178.0 & 170.0 & 199.0 & 57.4 & & & \\
\hline & & & $\max$. & 222.0 & 219.0 & 255.0 & 122.0 & & & \\
\hline \multirow{3}{*}{$23 \mathrm{Mar}-2 \mathrm{Apr}$} & \multirow{3}{*}{$\mathrm{F}$} & \multirow{3}{*}{39} & mean & 214.5 & 203.7 & 238.0 & 88.2 & \multirow{3}{*}{7} & \multirow{3}{*}{31} & \multirow{3}{*}{1} \\
\hline & & & $\min$ & 179.0 & 169.0 & 198.0 & 45.2 & & & \\
\hline & & & $\max$ & 248.0 & 233.0 & 272.0 & 139.6 & & & \\
\hline 29 Jun-14 Jul & $\mathrm{F}+\mathrm{M}$ & 132 & mean & 198.1 & 188.8 & 221.6 & 85.1 & 74 & 58 & - \\
\hline \multirow{3}{*}{29 Jun-14 Jul } & \multirow{3}{*}{ M } & \multirow{3}{*}{84} & mean & 196.9 & 187.7 & 220.6 & 83.0 & \multirow{3}{*}{47} & \multirow{3}{*}{37} & \multirow{3}{*}{-} \\
\hline & & & $\min$. & 171.0 & 161.0 & 180.0 & 58.6 & & & \\
\hline & & & $\max$ & 226.0 & 215.0 & 254.0 & 118.5 & & & \\
\hline \multirow{3}{*}{29 Jun-14 Jul } & \multirow{3}{*}{$\mathrm{F}$} & \multirow{3}{*}{48} & mean & 200.0 & 190.6 & 223.5 & 88.6 & \multirow{3}{*}{27} & \multirow{3}{*}{21} & \\
\hline & & & $\min$. & 175.0 & 167.0 & 196.0 & 67.3 & & & \multirow[t]{2}{*}{ - } \\
\hline & & & $\max$. & 230.0 & 220.0 & 261.0 & 135.3 & & & \\
\hline
\end{tabular}

The entire batch of fish examined consisted of 209 (46.3\%) females and 242 $(53.7 \%)$ males. A certain temporal pattern was evident: the spring and summer catches were dominated by males (85 individuals or $68.55 \%$ and 84 individuals or $63.6 \%$, respectively), while the catches from the two subsequent seasons, i.e. last summer and late autumn were dominated by females (53 individuals or $60.95 \%$ and 69 individuals or $63.9 \%$, respectively). The vendace aged $1+$ consisted of 108 females and 105 males. The 2+ group was formed by 96 females and 133 males, the latter being most abundant in the first half of the year (104 individuals). The group of 9 fish aged 3+ was made up by 5 females and 4 males. 
Table 2

Basic biological characteristics of Lake Miedwie vendace (late summer and autumn 1998)

\begin{tabular}{|c|c|c|c|c|c|c|c|c|c|c|}
\hline \multirow[t]{2}{*}{ Sampling period } & \multirow{2}{*}{ Sex } & \multirow{2}{*}{$\mathrm{n}$} & \multirow{2}{*}{ Value } & \multirow{2}{*}{$\begin{array}{c}\mathrm{FL} \\
{[\mathrm{mm}]}\end{array}$} & \multirow{2}{*}{$\begin{array}{c}\text { SL } \\
{[\mathrm{mm}]}\end{array}$} & \multirow{2}{*}{$\begin{array}{c}\mathrm{TL} \\
{[\mathrm{mm}]}\end{array}$} & \multirow{2}{*}{$\begin{array}{c}\text { Weight } \\
\left(W_{1}\right) \\
{[\mathrm{g}]}\end{array}$} & \multicolumn{3}{|c|}{ No. of fish aged: } \\
\hline & & & & & & & & $1+$ & $2+$ & $3+$ \\
\hline 18 Aug-9 Sep & $\mathrm{F}+\mathrm{M}$ & 87 & mean & 206.2 & 196.4 & 230.4 & 99.4 & 46 & 35 & 3 \\
\hline \multirow{3}{*}{18 Aug-9 Sep } & \multirow{3}{*}{ M } & \multirow{3}{*}{34} & mean & 198.7 & 189.1 & 221.6 & 85.7 & \multirow{3}{*}{23} & \multirow{3}{*}{11} & \multirow{3}{*}{ - } \\
\hline & & & min. & 178.0 & 170.0 & 203.0 & 60.1 & & & \\
\hline & & & $\max$ & 223.0 & 212.0 & 250.0 & 112.1 & & & \\
\hline \multirow{3}{*}{18 Aug-9 Sep } & \multirow{3}{*}{$\mathrm{F}$} & \multirow{3}{*}{53} & mean & 211.1 & 201.1 & 235.9 & 108.2 & \multirow{3}{*}{26} & \multirow{3}{*}{24} & \multirow{3}{*}{3} \\
\hline & & & $\min$. & 185.0 & 175.0 & 208.0 & 67.5 & & & \\
\hline & & & $\max$ & 246.0 & 233.0 & 276.0 & 174.1 & & & \\
\hline $16-25 \mathrm{Nov}$ & $\mathrm{F}+\mathrm{M}$ & 108 & mean & 208.4 & 198.1 & 232.7 & 95.2 & 66 & 38 & 4 \\
\hline \multirow{3}{*}{ 16-25 Nov } & \multirow{3}{*}{ M } & \multirow{3}{*}{39} & mean & 210.0 & 199.6 & 234.7 & 89.8 & \multirow{3}{*}{17} & \multirow{3}{*}{18} & \multirow{3}{*}{4} \\
\hline & & & min. & 184.0 & 176.0 & 212.0 & 71.1 & & & \\
\hline & & & $\max$ & 264.0 & 248.0 & 294.0 & 168.3 & & & \\
\hline \multirow{3}{*}{$16-25 \mathrm{Nov}$} & \multirow{3}{*}{$\mathrm{F}$} & \multirow{3}{*}{69} & mean & 207.4 & 197.3 & 231.5 & 98.2 & \multirow{3}{*}{49} & \multirow{3}{*}{20} & \multirow{3}{*}{ - } \\
\hline & & & $\min$. & 180.0 & 173.0 & 204.0 & 65.5 & & & \\
\hline & & & $\max$ & 256.0 & 241.0 & 288.0 & 176.3 & & & \\
\hline
\end{tabular}

Characteristics of the condition coefficients

Table 3 shows values of the Fulton- and Clark condition coefficients, the former based on the total weight and the other on the gutted fish weight, for different fishing seasons. Mean values of the Fulton coefficient showed a marked, typical of the vendace, increase in condition from spring to last summer, although the condition dropped in autumn. The Fulton coefficient was higher in females than in males. Noteworthy is the fact that the two condition coefficients tended to decrease with increasing total length and age of the fish (Fig. 2).

Table 3 shows also parameters of the total length-individual weight relationship of the vendace caught in different seasons and calculated for the entire material (Fig. 3). In most cases, values of the exponent $n$ exceeded 2.5, the exponent exceeding 3.0 in males caught in spring. A much higher temporal variability was displayed by the constant $a$, which ranged from 0.00006 to 0.0005 . Noteworthy is also a pattern, whereby the higher the value of $b$, the lower the value of $a$. 
Czerniejewski et al.

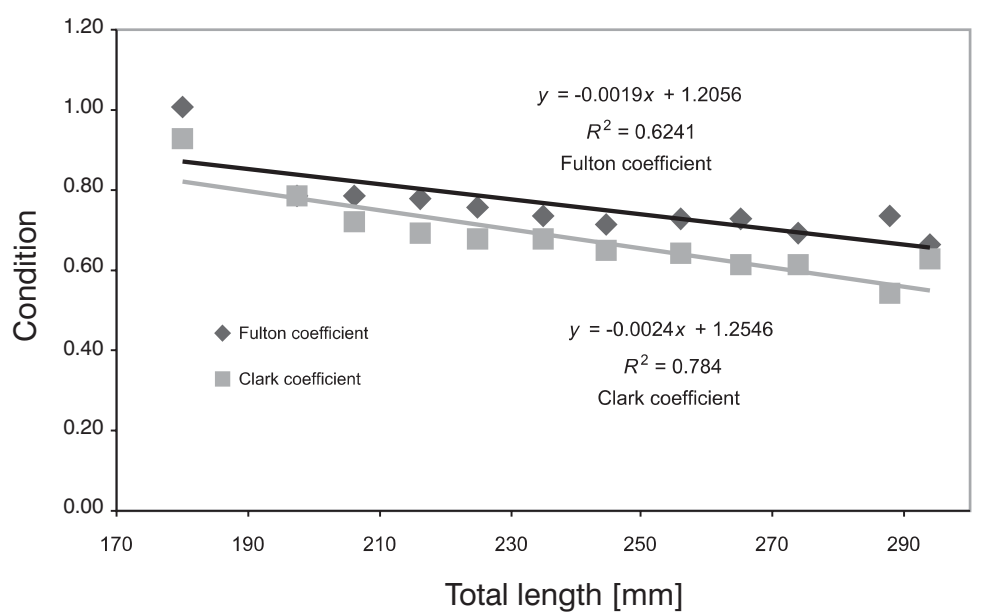

Fig. 2. Vendace condition versus total length

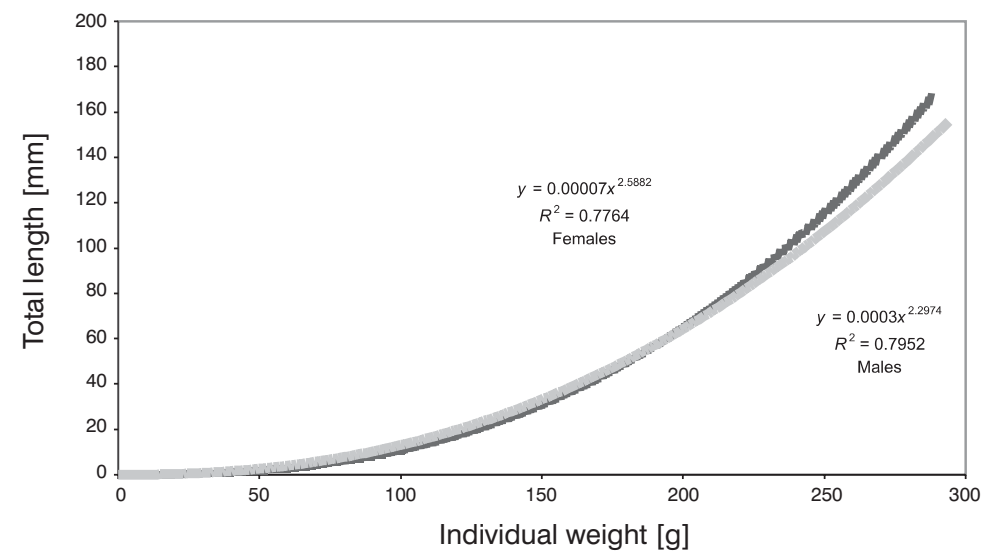

Fig. 3. Length-weight relationship in Lake Miedwie vendace

Gonads and gonadosomatic index

Gonads were analysed in 108 individuals (69 females and 39 males) harvested in the second and third decade of November 1998. Most fish had gonads at the final maturity stage, no female being spent. Due to the considerable thermal capacity of Lake Miedwie, resulting from, i.e. its large volume, the vendace spawn there-as a rule - at the turn of November and December, when the water temperature drops to 6-6.5 $5^{\circ}$. The Lake Miedwie vendace spawn much later than their conspecifics inhabiting other vendace lakes located near Miedwie. It is probably for this reason, too, there are grounds to presume that the vendace spawning in Lake Miedwie is very intense and short. The gonad weight of the 69 ready-to-spawn females averaged 22.05 g (range: $13.2-38.1 \mathrm{~g}$ ), making up $22.65 \%(13.2-31.1 \%)$ of the total body weight. 
The male gonad weight ranged within 0.75-3.18 g (mean: $1.72 \mathrm{~g}$ ), accounting for $0.84-3.54 \%$ (mean: $1.92 \%$ ) of the total body weight.

Table 3

Condition coefficients and $L-W$ relationship parameters of Lake Miedwie vendace

\begin{tabular}{|c|c|c|c|c|c|c|c|}
\hline \multirow{3}{*}{ Sampling period } & & \multicolumn{2}{|c|}{ Condition coefficient } & \multicolumn{4}{|c|}{$L-W$ relationship parameters } \\
\hline & \multirow[b]{2}{*}{ Sex } & \multirow{2}{*}{$\begin{array}{c}\text { Fulton } K \\
\bar{x} \pm s\end{array}$} & \multirow{2}{*}{$\begin{array}{c}\text { Clark } K_{\mathrm{c}} \\
\bar{x} \pm s\end{array}$} & \multirow[b]{2}{*}{$a$} & \multirow[b]{2}{*}{$b$} & \multirow[b]{2}{*}{$R^{2}$} & \multirow[b]{2}{*}{$n$} \\
\hline & & & & & & & \\
\hline \multirow{3}{*}{$23 \mathrm{Mar}-2 \mathrm{Apr}$} & $\mathrm{F}+\mathrm{M}$ & $0.70 \pm 0.06$ & $*$ & 0.00005 & 2.642 & 0.76 & 124 \\
\hline & M & $0.72 \pm 0.05$ & $*$ & 0.000006 & 3.021 & 0.91 & 85 \\
\hline & $\mathrm{F}$ & $0.78 \pm 0.04$ & $*$ & 0.00001 & 2.899 & 0.77 & 39 \\
\hline \multirow{3}{*}{ 29 Jun-14 Jul } & $\mathrm{F}+\mathrm{M}$ & $0.78 \pm 0.05$ & $0.72 \pm 0.05$ & 0.0002 & 2.397 & 0.89 & 132 \\
\hline & M & $0.77 \pm 0.05$ & $0.71 \pm 0.05$ & 0.0002 & 2.376 & 0.90 & 84 \\
\hline & $\mathrm{F}$ & $0.79 \pm 0.06$ & $0.72 \pm 0.05$ & 0.0002 & 2.366 & 0.89 & 48 \\
\hline \multirow{3}{*}{18 Aug-9 Sep } & $\mathrm{F}+\mathrm{M}$ & $0.80 \pm 0.06$ & $0.72 \pm 0.06$ & 0.00002 & 2.867 & 0.87 & 87 \\
\hline & M & $0.78 \pm 0.06$ & $0.72 \pm 0.05$ & 0.00002 & 2.852 & 0.80 & 34 \\
\hline & $\mathrm{F}$ & $0.82 \pm 0.07$ & $0.72 \pm 0.06$ & 0.00006 & 2.639 & 0.86 & 53 \\
\hline \multirow{3}{*}{$6-25 \mathrm{Nov}$} & $\mathrm{F}+\mathrm{M}$ & $0.75 \pm 0.07$ & $0.60 \pm 0.06$ & 0.0001 & 2.504 & 0.83 & 108 \\
\hline & M & $0.69 \pm 0.06$ & $0.65 \pm 0.06$ & 0.0005 & 2.206 & 0.88 & 39 \\
\hline & $\mathrm{F}$ & $0.78 \pm 0.05$ & $0.57 \pm 0.06$ & 0.00002 & 2.798 & 0.93 & 69 \\
\hline \multirow{3}{*}{ Total 1998} & $\mathrm{~F}+\mathrm{M}$ & $0.75 \pm 0.07$ & $0.68 \pm 0.08$ & 0.0001 & 2.523 & 0.79 & 451 \\
\hline & M & $0.74 \pm 0.06$ & $0.70 \pm 0.06$ & 0.0003 & 2.297 & 0.80 & 242 \\
\hline & $\mathrm{F}$ & $0.77 \pm 0.06$ & $0.66 \pm 0.09$ & 0.00007 & 2.588 & 0.78 & 209 \\
\hline
\end{tabular}

* not calculated

Vendace length and weight growth rate

Table 4 summarises results of back calculations-based length growth determination for the vendace studied. The Lake Miedwie vendace showed the highest length increments in their first year of life $(126.9 \mathrm{~mm}$, on the average), the increments being almost half that high in the second and third year, compared to the values from the preceding year. The variability in total length in different years of life, as expressed by the standard deviation, decreased from the youngest to the oldest fish. The back-calculated data for the entire material served to calculate the von Bertalanffy equation-based length growth model, the appropriate equation being as follows:

$$
L_{\mathrm{t}}=315.67\left[1-e^{-0.5204(t+0.00727)}\right]
$$

Differences between the results obtained with the two methods applied for consecutive years of life were small and averaged 1.9, 2.2, and $8.8 \mathrm{~mm}$ for $l_{1}, l_{2}$, and $l_{3}$, respectively. 
Table 5 summarises data on weight growth rate as calculated by converting total lengths to body weight with the $L-W$ relationship (the basic method) and by applying the von Bertalanffy equation. The latter model is expressed as

$$
W_{\mathrm{t}}=201.52\left[1-e^{-0.5204(\mathrm{t}+0.00727)}\right]^{2.5225}
$$

Results obtained with the two models differed slightly only, the differences amounting to $0.2(0.98 \%), 2.0 \mathrm{~g}(2.88 \%)$, and $9.3 \mathrm{~g}(8.34 \%)$ for the fish aged $1+, 2+$, and $3+$, respectively. Except for the latter, higher individual weight were obtained when using the length to weight conversion (the $L-W$ relationship).

Table 4

Length growth rate of vendace, as determined by back calculations and mathematical model based on the von Bertalanffy equation

\begin{tabular}{ccccc}
\hline \multirow{2}{*}{ Age groups } & \multicolumn{3}{c}{ Total length [mm] } \\
\cline { 2 - 5 } & $\mathrm{n}$ & $l_{1}$ & $l_{2}$ & $l_{3}$ \\
\hline I & 213 & 124.6 & 205.2 & 239.5 \\
II & 229 & 127.2 & 206.9 & 240.9 \\
III & 9 & 128.9 & 208.2 & 242.3 \\
mean & 451 & 126.9 & 206.8 & 240.9 \\
$s$ & & 2.17 & 1.50 & 1.40 \\
$\Delta l$ & & 126.9 & 79.9 & 34.1 \\
$n$ & & 451 & 238 & 9 \\
$L_{\mathrm{t}}{ }^{*}$ & & 128.8 & 204.6 & 249.7 \\
$L_{\mathrm{oo}}$ & & & 315.67 & \\
\hline
\end{tabular}

*as determined by von Bertalanffy equation.

Table 5

Weight growth rate of vendace (g), as determined by the basic method and modified von Bertalanffy equation

\begin{tabular}{ccc}
\hline \multirow{2}{*}{ Age in years } & \multicolumn{2}{c}{ Method } \\
\cline { 2 - 3 } 1 & Basic* & Von Bertalanffy \\
\hline 2 & 20.3 & 20.1 \\
3 & 69.5 & 67.5 \\
& 102.2 & 111.5 \\
\hline
\end{tabular}

*length to weight conversion with the $L-W$ relationship. 


\section{DISCUSSION}

The vendace is harvested in Poland mainly with $24 \mathrm{~mm}$ mesh size gill nets, which makes it possible to catch fish within the length range of 17.8 to $24.2 \mathrm{~cm}$, the length of fish caught with the maximum efficiency being $21.0 \mathrm{~cm}$ (Ciepielewski 1974b). The wider range reported from Lake Miedwie in this study was caused, on the one hand, by using 24 and $26 \mathrm{~mm}$ mesh size nets and, on the other, by the fact that, in addition to the fish "correctly" entangled by the nets, about $10 \%$ of the catch consisted of much larger individuals whose protrusions on the body stuck them in the net.

Assessment of the condition of individual fish is an important component of studies on various fish populations. According to a summary provided by Bolgier and Connolly (1989), variability of fish condition is studied most frequently from the length-weight relationship and with the use of mathematical formulae developed by Fulton, Clark, and Le Cren (Bolgier and Connoly 1989). The length-weight relationship usually assumes the form of a power function. The function exponent depends on, i.e. fish shape: it does not reach 3 in slender-bodied fish, while higher values are produced by more "stocky" fish (Wootton 1996). In vendace, the parameter oscillates around 3 (Christianus 1995, Czerniejewski and Filipiak 2002), which indicates isometry in the growth of the species. However, in some lakes with poor crustacean zooplankton resources and environmental conditions unfavourable for the vendace, the exponent does not exceed 2.5 (Czerniejewski and Filipiak 2002, Czerniejewski et al. 2002). Mean values of constant b in the $L-W$ relationship of the Lake Miedwie vendace assumed values similar to those reported by the authors referred to above. Differences in the values of parameters describing the vendace condition may have been caused by different harvesting season and/or by disregarding fish length effects in the analyses. The latter factor is particularly important, since the Lake Miedwie vendace showed a clear reduction in various condition coefficients with fish length.

The vendace is regarded as a pelagic fish with a relatively short life cycle, the fish aged $2+$ accounting for as much as $70 \%$ of the commercial catches. The appropriately high contribution of that year class to the catches is a result of the vendace growth being most intensive during the first three years of life (Bernatowicz et al. 1975). The too high contribution of the fish aged 1+ to the vendace catches in Lake Miedwie may contribute to a reduction in the catch (by weight) in the subsequent years.

It is difficult to compare growth rates between the vendace harvested from different lakes due to wide differences in the parameters in consecutive years of life and because of different timing of the annual ring appearance on the scales (Bernatowicz 1952). For example, as reported by Ciepielewski (1971), the vendace inhabiting the mesotrophic Lake Pluszne shows the scales to appear in spring-summer (May-June); in the eutrophic Lake Maróz, the process begins in autumn and proceeds until the beginning of summer, while all the Lake Miedwie individuals show an annual ring and a small edge increment in June. According to Marciak (1970), the vendace grow well when the total length in the third year of life amounts to $21.5-22.5 \mathrm{~cm}$, the very good growth 
being evidenced by the total length exceeding $22.5 \mathrm{~cm}$. Szczerbowski (1978) considers the growth to be fast when the vendace attain $23.7 \mathrm{~cm}$ in the same year. In the light of those literature data, the Lake Miedwie vendace caught in 1998 were characterised by very good growth, much better than that reported for other Western Pomeranian lakes: the Trześniowskie, Cieszęcin, Płęsno, Morzycko, and Pełcz (Marciak 1970, Czerniejewski and Czerniawski 2003) and the vendace lakes of Masuria (Table 6).

According to Bernatowicz (1963), the fastest growth rate is typical of the vendace inhabiting lakes very rich in crustacean zooplankton, affected by considerable oxygen deficiency in the hypolimnion, and failing to provide favourable conditions for vendace's natural spawning. The recent studies of Szlauer (1999) demonstrated rich zooplankton resources in the Miedwie (at the level of $0.96 \mathrm{mg} \cdot \mathrm{l}^{-1}$ ). This is an indication of a considerable improvement in environmental conditions of the lake and its return to mesotrophy.

Table 6

Vendace growth rates in different Polish lakes

\begin{tabular}{|c|c|c|c|c|c|c|c|c|}
\hline \multirow{2}{*}{ Region } & \multirow{2}{*}{ Lake } & \multicolumn{6}{|c|}{ Total length $[\mathrm{cm}]$ in different years of live } & \multirow{2}{*}{ Source } \\
\hline & & 1 & 2 & 3 & 4 & 5 & 6 & \\
\hline \multirow{13}{*}{ 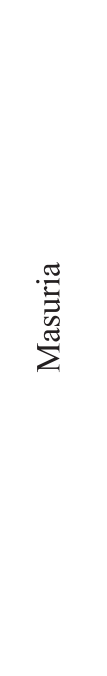 } & Dobskie & 14.5 & 20.4 & 23.2 & 24.9 & 26.5 & - & \multirow[t]{13}{*}{ Bernatowicz 1953} \\
\hline & Mamry Płn. & 14.5 & 19.7 & 22.9 & 25.3 & 27.5 & - & \\
\hline & Harsz & 12.7 & 19.4 & 22.5 & 24.9 & 25.2 & - & \\
\hline & Kisajno & 13.8 & 19.7 & 22.4 & 23.5 & - & - & \\
\hline & Gołdopiwo & 9.1 & 14.5 & 20.5 & 23.3 & 25.0 & 27.3 & \\
\hline & Buwełno & 8.7 & 13.8 & 18.9 & 20.9 & 23.3 & 26.5 & \\
\hline & Rydzówka & 7.8 & 13.6 & 18.7 & 20.8 & 23.7 & 27.0 & \\
\hline & Jagodne & 9.5 & 13.9 & 18.6 & 20.9 & 23.0 & 25.5 & \\
\hline & Tałty & 9.5 & 14.1 & 18.4 & 20.7 & 21.3 & - & \\
\hline & Maróz & 9.5 & 13.7 & 15.8 & 19.2 & - & - & \\
\hline & Lutry & 10.7 & 14.6 & 15.6 & - & - & - & \\
\hline & Narie & 9.5 & 14.5 & 16.6 & 17.1 & - & - & \\
\hline & Isag & 11.4 & 16.7 & 19.1 & 21.4 & - & - & \\
\hline \multirow{8}{*}{ 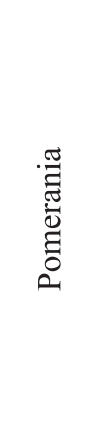 } & Trześniowskie & 9.5 & 16.7 & 20.1 & - & - & - & \multirow{5}{*}{ Marciak 1970} \\
\hline & Płęsno & 13.2 & 19.7 & 23.0 & - & - & - & \\
\hline & Cieszęcin & 9.9 & 18.1 & 22.9 & 25.9 & 27.4 & - & \\
\hline & Łętowo & 15.8 & 20.5 & 22.5 & - & - & - & \\
\hline & Ińsko & 13.7 & 20.5 & 23.5 & 26.3 & - & - & \\
\hline & Pełcz & 10.2 & 17.2 & 19.1 & - & - & - & Czerniejewski and \\
\hline & Morzycko & 12.1 & 18.8 & 21.5 & - & - & - & Czerniawski 2003 \\
\hline & Miedwie & 12.7 & 20.7 & 24.1 & - & - & - & This study \\
\hline
\end{tabular}


The fast self-restitution of the vendace, found in the Miedwie in the second half of the 1990s allows to hope that both the vendace and the common whitefish, recently abundant in catches, will-in the decades to come-constitute an important component of fisheries management of Lake Miedwie and one of the most important bioindicators of the environmental quality of the Lake. In this context, it seems purposeful and desirable to continue and to broaden the research on the Lake Miedwie vendace population, commenced in 1998.

\section{CONCLUSIONS}

1. The appearance of vendace in catches is an evidence of a considerable improvement in Lake Miedwie environmental conditions.

2. The individuals examined showed total length (mean: $228.49 \mathrm{~mm}$; range: $180.0-294.0 \mathrm{~mm}$ ) and individual weight (mean: $90.61 \mathrm{~g}$; range: $45.2-176.3 \mathrm{~g}$ ) to be typical of the vendace caught by 24 and $26 \mathrm{~mm}$ mesh size stationary gear. The wide ranges of length and weight resulted from the fact that some large individuals were stuck in the nets.

3. The Lake Miedwie vendace age structure showed an age distribution typical of the harvestable part of the stock $(1+$ through $3+)$ and a high, compared to other populations, contribution of individuals aged $1+(47.2 \%)$.

4. The length growth of the Lake Miedwie vendace was typical of a short-lived fish: substantial increments in the first year of life and a considerable (almost halved) reduction in increments during the subsequent years. According to the generally accepted criteria of the vendace growth rate, the Lake Miedwie individuals showed a very good growth, higher than that recorded in populations inhabiting other whitefish lakes of Western Pomerania, which indicates the availability of appropriate food resources for the vendace in the Miedwie. Also, fast growth would be expected during the first years of recolonisation, because there is not yet an intraspecific competition for food.

5. The condition coefficients and parameters of the $L-W$ relationship, assessed for the Lake Miedwie vendace are close to those reported in the literature for the fish inhabiting other vendace lakes. Both the Fulton- and Clark coefficients are observed to slowly decrease with increasing total fish length.

\section{REFERENCES}

Anonymous, 1999. Raport o stanie środowiska w województwie Zachodniopomorskim w latach 1997-1998. [Report on the state of environment in the Province of Polish Western Pomerania in 1997-1998.] Państwowy Inspektorat Ochrony Środowiska, Biblioteka Monitoringu Środowiska, Szczecin. (In Polish.)

Anonymous, 2002. Raport o stanie środowiska w województwie Zachodniopomorskim. [Report on the state of the environment in the Province of Western Pomerania.] Państwowy Inspektorat Ochrony Środowiska, Biblioteka Monitoringu Środowiska, Szczecin. (In Polish.)

Bagenal T., (ed.) 1978. Methods for assessment of fish production in fresh waters. Third edition. Blackwell Scientific Publication, Oxford. 
Bernatowicz S., 1952. Zagadnienie trafności oznaczania wieku i przyrostu sielawy na podstawie łusek z różnych okolic. [On the problem of correct determination of growth and increments of vendace from scales collected from various parts of the body.] Roczniki Nauk Rolniczych B 65: 311-335. (In Polish.)

Bernatowicz S., 1953. Występowanie i przyrost sielawy jezior mazurskich na tle warunków środowiska. [The occurrence and growth of vendace in Masurian lakes in relation to environmental conditions.] Roczniki Nauk Rolniczych B 67: 1-20. (In Polish.)

Bernatowicz S., 1963. Obserwacje nad rozwojem sielawy w kompleksie jeziora Mamry. [Observation on the development of common whitefish in the Lake Mamry complex.] Roczniki Nauk Rolniczych B 82: 337-352. (In Polish.)

Bernatowicz S., Dembiński W., Radziej J., 1975. Sielawa. [The vendace.] PWRiL, Warszawa. (In Polish.)

Bolgier T., Connolly P.L., 1989. The selection of suitable indices for the measurement and analysis of fish condition. Journal of Fish Biology 34: 171-182.

Brylińska M., (ed.) 1986. Ryby słodkowodne Polski. [The freshwater fishes of Poland.] PWN, Warszawa. (In Polish.)

Christianus J., 1995. Age and growth of selected vendace (Coregonus albula L.) populations in Poland. Archiv für Hydrobiologie, Special Issues in Advanced Limnology 46: 97-102.

Ciepielewski W., 1971. Tworzenie się pierścienia rocznego na łuskach sielawy (Coregonus albula L.). [Formation of the annual ring on scales of vendace (Coregonus albula L.).] Roczniki Nauk Rolniczych H 93: 25-34. (In Polish.)

Ciepielewski W., 1974a. Względne liczebności roczników sielawy w jeziorze Maróz. [Relative abundance of vendace year-classes in Lake Maróz.] Roczniki Nauk Rolniczych H 96: 31-47. (In Polish.)

Ciepielewski W., 1974b. Selektywność wontonów sielawowych. [Selectivity of vendace gillnets.] Roczniki Nauk Rolniczych H 96: 17-29. (In Polish.)

Czerniejewski P., Czerniawski R., 2003. Age, growth and condition of vendace Coregonus albula (L.) from Lakes Morzyczko and Pelcz (N-W Poland). Zoologica Poloniae (In press.)

Czerniejewski P., Filipiak J., 2001. Występowanie sielawy (Coregonus albula L.) w jeziorach Pomorza Zachodniego. [The occurrence of vendace (Coregonus albula L.) in Western Pomeranian lakes.] Komunikaty Rybackie 52001 (64): 3-7. (In Polish.)

Czerniejewski P., Filipiak J., 2002. Biological and morphological characteristics of vendace, Coregonus albula L, from lakes Drawsko and Pełcz. Acta Ichthyologica et Piscatoria 32 (1): 53-69.

Czerniejewski P., Filipiak J., Przybył A., 2002. Biological characteristics of vendace (Coregonus albula L.) from the Tuczno Wielkie and Siecino lakes. Scientific Papers of Agricultural University of Poznań, Seria Animal Science 4: 77-90.

Dembiński W., 1971. Vertical distribution of vendace Coregonus albula L. and other pelagic fish species in some Polish lakes. Journal of Fish Biology 3: 341-357.

Filipiak J., Raczyński M., 2000. Jeziora Zachodniopomorskie (Zarys faktografii). [Lakes of Polish Western Pomerania; fact sheets.] Wydawnictwo AR Szczecin. (In Polish.)

Grudniewski C., 1970. Zakładanie się łusek u sielawy (Coregonus albula L.). [Establishment of scales in vendace (Coregonus albula L.).] Roczniki Nauk Rolniczych H 92: 17-25. (In Polish.)

Jańczak J., (ed.) 1996. Atlas jezior Polski. Atlas Pojezierza Wielkopolskiego i Pomorskiego w granicach dorzecza Odry. [Atlas of Polish lakes. Atlas of the Lake Districts of Great 
Poland and Polish Western Pomerania within the Odra River drainage basins.] Bogucki Wydawnictwo Naukowe, Poznań. (In Polish.)

Kudelska D., Cydzik D., Soszka H., 1992. Wytyczne monitoringu podstawowego jazior. [Guidelines for basic monitoring of lakes.] Wydawnictwo PIOŚ, Warszawa. (In Polish.)

Marciak Z., 1970. Zagospodarowanie jezior sielawą. [Vendace management in lakes.] Wydawnictwo IRS, Olsztyn No. 39. (In Polish.)

Ovchynnuk M.M., 1962. The use of scales and bones for age determination of the Great Lakes whitefish Coregonus clupeaformis clupeaformis. Zoologischer Anzeiger 169 (5-6): $198-217$.

Pietrucha M., 1999. Powrót siejowatych (Coregonus lavaretus maraena B. i Coregonus albula L.) do jeziora Miedwie. [The return of coregonids (Coregonus lavaretus maraena B. and Coregonus albula L.) to Lake Miedwie.] Komunikaty Rybackie 31999 (50): 14-19. (In Polish.)

Sych R., 1971. Elements of theory of determining fish age from scales. Problem of reliability. Roczniki Nauk Rolniczych B 67 (1): 21-36.

Szczerbowski J.A., 1978. Ocena tempa wzrostu sielawy, siei, leszcza, płoci i sandacza, jako podstawy określania wymiaru gospodarczego. [An assessment of the growth rates of vendace, common whitefish, carp bream, roach, and zander as a basis for determining the marketable size.] Wydawnictwo IRS, Olsztyn No. 114. (In Polish.)

Szlauer B., 1999. Zooplankton-based evaluation of the state of Lake Miewie (north-western Poland). Electronic Journal of Polish Agricultural Universities, Seria Piscaria 2: 1-20.

Szyper H., Gołdyn R., 1990. Studium ochrony jeziora Miedwie jako źródła wody pitnej dla Szczecina. [A study on the protection of Lake Miedwie as a source of drinking water for the city of Szczecin.] Wydawnictwo IGPiK, Poznań. (In Polish.)

Tórz A., Kubiak J., Chojnacki J.C., 2003. Assessment of Lake Miedwie water quality in 1998-2001. Acta Scientiarum Polonorum, Seria Piscaria 2 (1): 279-290.

Vollenweider R., Kerekes J., 1982. Eutrophication of waters, Monitoring, Assessment and Control. OECD, Paris.

Wootton R.J., 1996. Ecology of teleost fishes. Chapman and Hall, London.

Żmudziński L., 2003. Zubożenie zoobentosu wyrazem eutrofizacji słynnego oligotroficznego jeziora Miedwie zasiedlonego pierwotnie przez trzy postglacjalne gatunki skorupiaków reliktowych. [Zoobenthos decline, as a sign of eutrophication of the famous oligotrophic Lake Miedwie inhabited originally by three postglacial relict crustacean species.] pp 128-134. In: Rogalska S., Domagała J., (eds.) Człowiek i środowisko przyrodnicze Pomorza Zachodniego. Część I. Środowisko biotyczne. [Humans and the natural environment of Polish Western Pomerania. Part 1. Biotic environment.] Oficyna in Plus, Szczecin. (In Polish.)

Received: 12 August 2004 Accepted: 22 December 2004 